Perspective

\title{
Is OPEC dead? Oil exporters, the Paris agreement and the transition to a post-carbon world
}

\author{
Thijs Van de Graaf \\ Department of Political Science, Ghent University, Belgium
}

\section{A R T I C L E I N F O}

\section{Article history:}

Received 11 October 2016

Accepted 13 October 2016

Available online $\mathrm{xxx}$

\section{Keywords:}

Organization of the Petroleum-Exporting

Countries (OPEC)

Paris Climate Agreement

Oil demand peak

Stranded assets

\begin{abstract}
A B S T R A C T
The Organization of the Petroleum-Exporting Countries (OPEC) faces a perfect storm. It is squeezed between the revolution in unconventionals, which has increased global supply of hydrocarbons and lowered their price, and the prospect of a global peak in oil demand, stemming from climate policies and the falling costs of alternative energy technologies. In the face of these challenges, media commentators have declared the death of OPEC as a cartel. This perspective argues that the claims about OPEC's demise are misguided for four reasons: (1) OPEC never acted as a cartel, let alone a powerful one; (2) thanks to its cheap production costs, OPEC's oil will remain competitive in a low-cost environment; (3) the group has always proved to be flexible; and (4) OPEC is still attractive to its member states, most notably as a source of prestige, as is illustrated by the recent re-entries of Indonesia and Gabon. That said, over the longer term OPEC will inevitably need to adapt to a changing external environment. A likely possibility would be for the club to gradually morph from an output-setting cartel into a forum for deliberation and information-sharing.
\end{abstract}

(c) 2016 Elsevier Ltd. All rights reserved.

\section{Introduction}

OPEC is facing some of the most severe threats in its almost 60year history. The 'fracking revolution' has unlocked large swaths of new oil and gas supplies, contributing to a global glut. Alternative energy technologies are seeing impressive falls in costs-with solar photovoltaics prices dropping more than 60\% between 2009 and 2016 [1]. A new climate treaty was adopted by 195 nations in December 2015, aiming to limit climate change to 'well below' $2^{\circ} \mathrm{C}$, which would render the bulk of fossil fuel reserves 'unburnable' [2]. On top of that, the dramatic fall in oil prices since mid-2014, after a four-year period of relatively stable and high prices, has exposed the economic fragility of many OPEC countries who are heavily reliant on revenues from the foreign sales of crude oil, most notably Venezuela, which saw its economy shrink by 5.7\% in 2015 [3].

The self-proclaimed cartel has failed to adopt a coherent, united stance in response to these colluding challenges. At a dramatic meeting in November 2014, OPEC defied expectations that it would cut supply and shore up the price, opting instead to let market forces play out. OPEC had an official production ceiling of 30 million barrels a day (mb/d) since 2012 [4], but the target was effectively

E-mail address: thijs.vandegraaf@ugent.be abandoned in December 2015 when the group ended its semiannual meeting without specifying new production quotas [5]. OPEC's inaction in 2014 stands in stark contrast to its response to the oil price crashes of 1998 and 2008, when the organization orchestrated major production cutbacks. The decision not to lower the production quotas in November 2014 is largely attributed to Saudi Arabia and its main concern that any cut in its production would have been offset by an increase in production from within and outside OPEC, without inducing a lasting price recovery [6]. The Saudis and their neighbors instead dramatically increased their production in an apparent bid to drive prices further down and force high-cost suppliers out of the market.

The inability of OPEC to agree to production cuts triggered a battle for market share, both inside and outside the cartel (see Fig. 1). OPEC's laissez-faire oil policy prompted the International Energy Agency (IEA) to observe, quite remarkably, that in 2016, we are living in perhaps the first truly free oil market we have seen since the pioneering days of the industry [7].' An attempt to forge a 'production freeze' (not to be conflated with a production cut) between OPEC countries and Russia at a meeting in Doha in April 2016 utterly failed. The talks collapsed at the 11th hour after Saudi Arabia refused to sign a deal without Iran, which in turn did not want to participate in a production freeze, arguing it needed to recapture market share lost while it was under international sanctions. Another attempt in September 2016 seemed more successful, 
12000

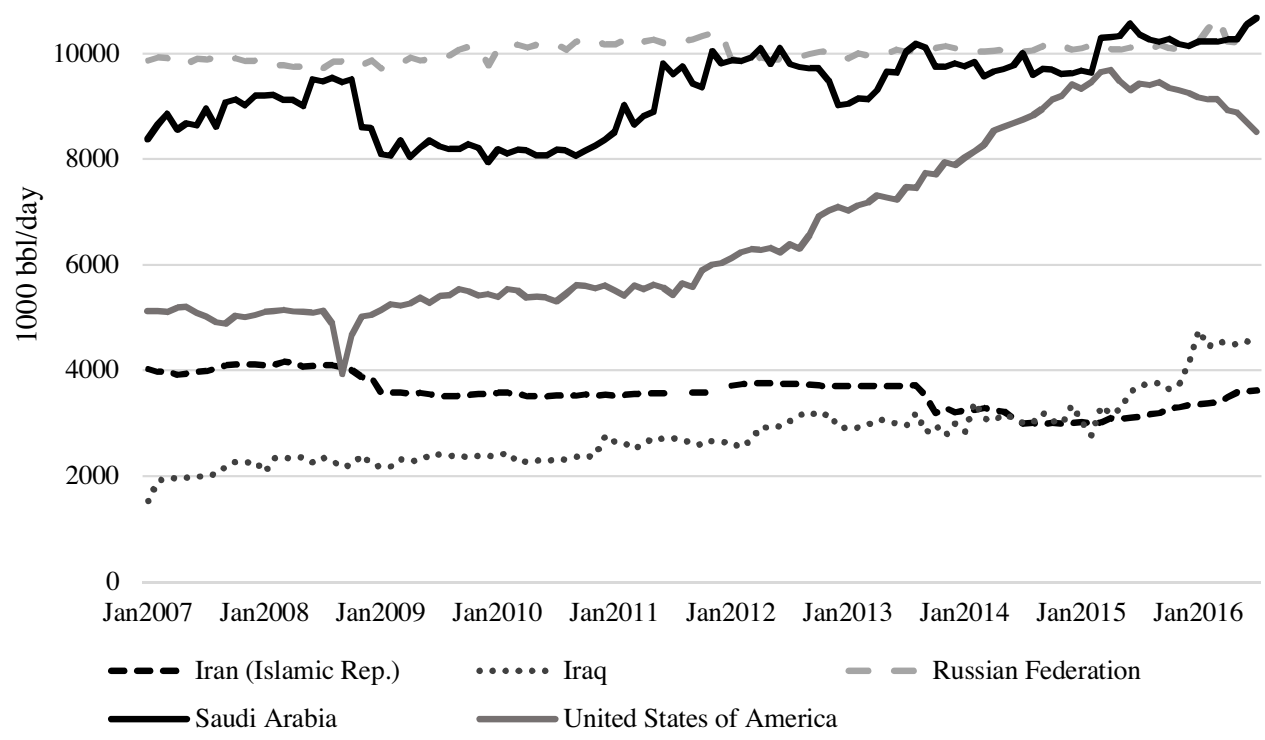

Fig. 1. Battling for market share: monthly output by selected producers.

Source: JODI: https://www.jodidata.org/oil/, consulted on October 11, 2016.

with OPEC countries agreeing to adopt a production target 'ranging between 32.5 and $33.0 \mathrm{mb} / \mathrm{d}$ [8]'. While OPEC may appear to reassert itself with this deal, observers remained skeptical whether (i) OPEC countries would actually follow through on this commitment; and (ii) whether such a production cut could have major knock-on effects on global prices, in light of the large inventory overhang that needs to be cleared first.

Yet, the battle for market share is only half the story. With its vast and cheap oil reserves, Saudi Arabia has long been wary of 'demand destruction' and wants to keep oil consumers hooked to oil, as was illustrated in a US Department of State cable that was made public by Wikileaks. 'Saudi officials are very concerned that a climate change treaty would significantly reduce their income,' James Smith, the U.S. ambassador to Riyadh, wrote in a 2010 memo to U.S. Energy Secretary Steven Chu. 'Effectively, peak oil arguments have been replaced by peak demand.' It thus seems reasonable to assume that for Saudi officials, low oil prices also serve as a hedge against rising tide of fuel economy, biofuels, electric vehicles, natural gas vehicles, advances in energy storage, et cetera.

Two years onwards, OPEC's market share strategy has done little to lift oil prices-the oil price has been stuck for months in a $\$ 40-\$ 50$ price-per-barrel band. To make matters worse, OPEC has in recent years been riven by internal quarrels and rifts, including proxy wars between Saudi Arabia and Iran in both Yemen and Syria. Several OPEC countries are facing domestic political instability, particularly Libya (which, after Gaddafi, has been riven by conflict between East and West) [9], Venezuela (which has seen a series of mass protests, political demonstrations, and civil insurrection since 2014), and Nigeria (where repeated acts of sabotage by a militant group called the 'Niger Delta Avengers' has taken the country's oil production near 30-year lows) [10]. Moreover, Saudi Arabia, still the cartel's informal leader, has sacked its long-serving oil minister Ali al-Naimi in May 2016 and announced a plan (dubbed 'Vision 2030') to wean its economy off from oil.

Some analysts suggest that the cartel's failure to reach a united position 'is not merely a sign that its influence is at a cyclical low ebb, but rather a portent of a more structural shift into irrelevance [11].' By announcing a national plan to wean the kingdom's economy off oil revenue, Saudi Arabia is said to 'sounding the group's death knell.' Even within the organization itself, the view is gaining root that the club is in decay. At the May 2016 OPEC board of governors meeting in Vienna, a representative from a 'non-Gulf Arab country' pronounced OPEC dead [12]. Predictions of OPEC's demise have a long history, of course, and so far they have always proven to be exaggerated [13]. Yet, some analysts, such as Ed Morse from the investment bank Citigroup, maintain that 'this time around might well be different [14],' because the shale revolution has heralded a 'new oil order [15].'

This perspective argues that OPEC does indeed face a dramatically altered external environment, brought about by three main trends: the fracking revolution and the risk of prolonged low oil prices, tightening climate policies, and cheaper alternatives to oil [16]. Yet, the claims about OPEC's demise are misguided for four reasons. First, OPEC never was a powerful cartel anyway-in fact, it never actually was a cartel. Second, OPEC's oil will still find a market for years to come thanks to its favorable geology. Third, international organizations rarely die and OPEC has demonstrated a remarkable capacity to adapt to changing circumstances over its lifetime. Finally, despite its lack of action and cohesiveness, OPEC still provides many useful functions to its member states.

\section{A perfect storm: the geopolitics of oil abundance}

The conventional view of energy geopolitics has long been underpinned by the expectation that global demand for oil will continue to grow unabatedly. The geopolitics of energy used to be framed as a struggle for access to scarce oil and gas reserves-an image that is still often reproduced in the media. Soaring energy demand from rising economies and depletion of existing fields was thought to intensify the scramble, which would in turn inflate the power of OPEC and other big producers such as Russia [17]. Since the 2000s, when oil prices began to climb, OPEC comfortably believed that the oil-constrained world had arrived and its oil was more valuable under the ground than out in the market [18].

That common wisdom has now changed. The new geopolitics of energy is characterized by abundance rather than scarcity, even at low prices. In fact, OPEC countries might not be able to burn through all of their fossil fuel reserves due to climate change regulation. 


\begin{tabular}{|ll|}
\hline $\begin{array}{l}\text { Box 1: Past attempts by oil producers to stabilize pro- } \\
\text { duction and prices. } \\
\text { Source: Kemp [20]. }\end{array}$ \\
\hline Name & Date/Period \\
\hline Oil Creek Association & 1861 \\
Petroleum Producers Association of Pennsylvania & 1869 \\
Standard Oil & 19870 s-1910s \\
Achnacarry/As-Is Agreement & 1928 \\
Anglo-American Petroleum Agreement & 1944 \\
Seven Sisters & 1940 s-1970s \\
Texas Railroad Commission & 1940 s-1970s \\
OPEC & 1960 s-today \\
\hline
\end{tabular}

Key trends in efficiency, fuel-switching and market saturation are pointing into the direction of a demand peak for oil instead of a supply peak. Oil producers are coming to realize that oil in the ground is not like 'money in the bank' but that these resources might someday be less valuable than oil produced and sold in the short term [18]. The challenge of oil producers thus once more boils down to the question of 'how to organize scarcity in the face of prodigious abundance [19]', as it has so many times before (see Box 1).

\subsection{Abundant reserves}

The first crack in this conventional view of energy geopolitics arose due to the recent shale and fracking revolution, which has unlocked large new oil and gas deposits for commercial extraction. To be sure, tight oil and shale gas production comes at a price compared to conventional extraction, both in terms of higher exploration and production cost, a lower energy return on investment (EROI), and grave environmental and social risks. These costs and externalities, though, have not prevented the rapid and vast boom of the shale gas and tight oil industry in the United States, which alone added almost $4 \mathrm{mb} / \mathrm{d}$ of oil to the world's oil production between 2007 and 2015 (see Fig. 1). The IEA expects a number of countries to follow into the footsteps of the United States, with China likely in the vanguard, though it will take a few more years before their efforts to tap shale gas and tight oil deposits at a large scale will bear fruit [21].

There are other emerging sources of supply, next to shale oil, including biofuels, oil sands, deepwater deposits, and growing conventional production from countries like Iraq, which might substantially increase the global reserve base. Coupled with OPEC's rising internal demand and stagnant or even falling upstream capacity, the group's share of the export market might be eroded over time [22]. But the advent of the shale and tight oil industry stands out for three reasons [23].

First, by unlocking vast resources that had long been deemed uneconomical, the fracking technology has dispelled 'peak oil' worries just as rising climate concerns have begun to cast doubt on the long-term outlook for oil demand growth. This has fueled speculation that a huge 'carbon bubble' is in the making, that large amounts of oil would have to 'stay in the ground', and that some of OPEC's resources might end up being 'stranded assets'. This might change the revenue-maximizing strategy of low-cost producers like Saudi Arabia and give them an incentive to speed up, rather than slow down, oil extraction.

Second, the shale revolution accelerates the eastward migration of the global oil market, whereby the center of gravity of oil consumption, and hence oil trade flows, are decidedly shifting to the so-called 'East of Suez' region. That leaves oil exporters competing with each other for an increasingly concentrated Asian market, which is itself dominated by supergiant Chinese oil trading companies with considerable market power. This situation provides another deterrent for OPEC to implement production cuts.

Last but not least, what stands at the center of the shale oil revolution is that it has changed the cost curve and elasticity of oil supply. The fracking industry operates on a much shorter investment cycle than the conventional oil industry: upfront costs are relatively low, decline rates are steep, lead times and payback times are short. There is no real exploration process to speak of because the location and broad characteristics of the main plays are well known. The time from an investment decision to actual production is measured in months, rather than years, making the tight oil industry far more nimble and responsive to price signals [24].

While this does not necessarily mean that the tight oil industry can now operate as the new 'swing producer', it is very likely that the fracking industry will keep a lid on a possible price rebound. After a period of resilience thanks to improvements in productivity and drilling efficiency, shale oil has been the first respondent to the price decline, with production losses projected for 2016 estimated at around 900,000 barrels per day year-on-year [25]. It may again be the first respondent on the way up, but that depends on the industry's continued access to capital and labor, which is uncertain [26]. To the extent that this happens, shale might simply mitigate the volatility problem that has plagued oil markets for so long, which might not necessarily be a bad thing for low-cost producers in OPEC. But the smoothening effect of unconventional oil on the price curve might be detrimental for high-cost producers as it will exert downward pressure on long-term global crude oil prices.

\subsection{Shrinking demand}

At the demand side, the Paris Agreement concluded in December 2015 might prove to be a game-changer. Even though the text of the Agreement nowhere mentions the words 'oil', 'gas', 'energy', 'fossil fuels' or even 'carbon', the deal effectively implies a complete overhaul of the world's energy mix. By agreeing on the political goal of limiting average global surface temperature increase to 'well below' $2{ }^{\circ} \mathrm{C}$ above preindustrial levels and even try to keep it below $1.5^{\circ} \mathrm{C}$, the Paris Agreement boils down to a commitment to phase out fossil fuels entirely before the end of the century.

More specifically, the IPCC's latest Synthesis Report finds that, to have a likely ( $>66 \%$ ) chance of limiting warming to $2{ }^{\circ} \mathrm{C}$, net global carbon emissions will need to be reduced to zero by around 2065 (see Table 1). Such carbon neutrality does not imply zero emissions in all sectors. Remaining emissions in a certain country or sector (e.g., energy) could be compensated by $\mathrm{CO}_{2}$ removals achieved by afforestation and reforestation (in UNFCCC speak this is known as LULUCF: the uptake of $\mathrm{CO}_{2}$ due to human activities in the 'land use, land-use change, and forestry sector') or negative emissions like bioenergy in combination with $\mathrm{CO}_{2}$ capture and permanent geological storage (also known as BECCS) [27]. If the carbon budget is overspent, such negative global emissions could in theory also make up for the overspending [28].

Under a scenario where fossil fuel use is reduced to limit global warming to $2{ }^{\circ} \mathrm{C}$, oil will probably be phased out slower than coal which is far more polluting and has more substitutes. Yet, oil will certainly not be able to expand at the same pace as it used to. The IEA's latest 450 scenario, which is consistent with a $50 \%$ chance of less than $2{ }^{\circ} \mathrm{C}$ of global warming, projects global oil demand to reach a peak of 93.7 million b/d in 2020 after which it falls fall to 74.1 million b/d by 2040. This would imply that the oil industry's decades-old expansion would come to a halt and enter a permanent decline, implying that the oil would become an ex-growth sector. This could trigger a 'race to sell oil' among petrostates [30], among other strategies (see Table 2).

McGlade and Ekins have calculated that, globally, a third of oil reserves, half of gas reserves and over $80 \%$ of current coal reserves 
Table 1

Deadline to phase out energy-related emissions in 1.5 and $2{ }^{\circ}$ scenarios.

\begin{tabular}{|c|c|c|c|c|}
\hline \multirow[t]{2}{*}{ Global temperature goal ${ }^{a}$} & \multirow[t]{2}{*}{ Remaining carbon budget ${ }^{\mathrm{b}}$} & \multicolumn{3}{|l|}{ Timing of reaching net zero levels ${ }^{c}$} \\
\hline & & $\mathrm{CO}_{2}$ from energy and industry & Global total $\mathrm{CO}_{2}$ & Kyoto-GHGs \\
\hline $\begin{array}{l}2{ }^{\circ} \mathrm{C} \\
\text { medium chance } \\
(50 \%-66 \%)\end{array}$ & 1140 & 2080 & 2070 & 2100 \\
\hline $\begin{array}{l}2 \circ \mathrm{C} \\
\text { likely chance }(>66 \%)\end{array}$ & 790 & 2065 & 2065 & 2090 \\
\hline $\begin{array}{l}1.5^{\circ} \mathrm{C} \text {, } \\
\text { medium chance } \\
(50 \%-66 \%)\end{array}$ & 365 & 2055 & 2055 & 2080 \\
\hline
\end{tabular}

Source: Rogelj et al. [29].

a To be reached in 2100, relative to pre-industrial levels. Rounded to nearest $5 \mathrm{GtCO}_{2}$.

b Median estimate of cumulative $\mathrm{CO}_{2}$ emissions from 2011 to $2100\left(\mathrm{GtCO}_{2}\right)$.

c Median estimate, rounded to nearest 5 year.

Table 2

Strategic options of major oil exporters in a carbon-constrained world.

\begin{tabular}{|c|c|c|}
\hline Strategy & Description & Recent examples \\
\hline Quota agreements & $\begin{array}{l}\text { Exporters jointly agree on production quota to restrict output, } \\
\text { keep oil prices high, and thus preserve oil rents in the face of } \\
\text { falling demand. }\end{array}$ & $\begin{array}{l}\text { Attempts in April and September } 2016 \text { to 'freeze' production by a } \\
\text { number of major oil exporters, both from OPEC and non-OPEC } \\
\text { (Russia). }\end{array}$ \\
\hline Price wars & $\begin{array}{l}\text { Exporters engage in competitive price undercuts to gain market } \\
\text { share and sell as much oil as possible before oil assets become } \\
\text { stranded due to climate regulation. }\end{array}$ & $\begin{array}{l}\text { By pumping at record levels, OPEC and non-OPEC (mainly US tight } \\
\text { oil) producers are currently said to be engaged in a price war. }\end{array}$ \\
\hline Efficiency & $\begin{array}{l}\text { Exporters attempt to preserve rents by becoming more efficient in } \\
\text { how they produce petroleum and spend their oil revenues. }\end{array}$ & $\begin{array}{l}\text { Several OPEC countries have recently reformed domestic fuel } \\
\text { subsidies. Saudi Arabia is preparing an IPO of parts of Saudi } \\
\text { Aramco. }\end{array}$ \\
\hline Compensation & $\begin{array}{l}\text { Exporters strive for monetary compensation within the UNFCCC } \\
\text { process for their envisaged loss in oil revenues. }\end{array}$ & $\begin{array}{l}\text { In 2007, Ecuador proposed to leave nearly } 900 \text { million barrels of oil } \\
\text { underground in the Yasuni National Park if the international } \\
\text { community would pay } 50 \% \text { of the value of the reserves for the } \\
\text { avoided emissions to a trust fund. In } 2013 \text {, the initiative was } \\
\text { abandoned for lack of sufficient pledges. }\end{array}$ \\
\hline Diversification & $\begin{array}{l}\text { Exporters diversify their national economies to become less } \\
\text { dependent on the oil sector. }\end{array}$ & $\begin{array}{l}\text { Saudi Arabia has announced 'Vision } 2030 \text { ' - a plan to limit the } \\
\text { country's dependence on oil revenues. }\end{array}$ \\
\hline
\end{tabular}

Source: Van de Graaf and Verbruggen [31].

Table 3

Reserves unburnable before 2050 in a $2^{\circ} \mathrm{C}$ scenario with CCS.

\begin{tabular}{llll}
\hline & Oil & Gas & Coal \\
\hline Africa & $21 \%$ & $33 \%$ & $85 \%$ \\
Canada & $74 \%$ & $24 \%$ & $75 \%$ \\
China and India & $25 \%$ & $63 \%$ & $66 \%$ \\
FSU & $18 \%$ & $50 \%$ & $94 \%$ \\
CSA & $39 \%$ & $53 \%$ & $51 \%$ \\
Europe & $20 \%$ & $11 \%$ & $78 \%$ \\
Middle East & $38 \%$ & $61 \%$ & $99 \%$ \\
OECD Pacific & $37 \%$ & $56 \%$ & $93 \%$ \\
ODA & $9 \%$ & $24 \%$ & $34 \%$ \\
US & $6 \%$ & $4 \%$ & $92 \%$ \\
Global & $\mathbf{3 3 \%}$ & $\mathbf{4 9 \%}$ & $\mathbf{8 2} \%$ \\
\hline
\end{tabular}

Source: McGlade and Ekins [32].

Notes: FSU, the former Soviet Union countries; CSA, Central and South America; ODA, Other developing Asian countries; OECD, the Organisation for Economic Cooperation and Development. Bold value indicates the global average.

should remain unused from 2010 to 2050 in order to have a betterthan-even chance of meeting the target of $2^{\circ} \mathrm{C}$. These 'unburnable reserves' do not decrease very much in a scenario with widespread deployment of carbon capture and storage (CCS). For example, the amount of 'unburnable' oil inches slightly downwards from $35 \%$ to $33 \%$ of all reserves if CCS is widely deployed. The modest effect of CCS is due to the fact that CCS will take decades to scale up globally, the technique might not be more cost-effective than renewables or nuclear and it is not entirely carbon-free. Table 3 depicts the shares of fossil fuel reserves that should be kept under the ground to have a medium chance of limiting warming to $2^{\circ} \mathrm{C}$ in a scenario with CCS deployment.
Admittedly, there are good reasons to be skeptical about the outcome of COP21. Nobody knows what 'well below $2{ }^{\circ} \mathrm{C}$ ' really means, shipping and aviation are not included in the Paris Agreement, and current national pledges - if they are met - will likely set us on a path of $2.7-3.7^{\circ} \mathrm{C}$ of global warming by 2100 [33]. The Agreement does contain a commitment to renew and review the national pledges every five years, but it remains to be seen whether this will lead to a 'virtuous cycle' of strengthening mitigation ambition over time that is capable of closing the emissions gap.

Even if the $2{ }^{\circ} \mathrm{C}$ goal is not met, there are significant drivers that could lead to a peak in global oil demand, including lower economic growth (especially in emerging markets), the falling cost of renewables and electricity storage, the emergence of prosumers with a keen interest in electric vehicles, the spread of more stringent policies to mitigate air pollution or water stress, and the growing decoupling between oil consumption and economic growth due to greater efficiency [34]. In short, the writing is on the wall that oil will never again grow at its historic rates. As Fig. 2 shows, in only 9 of the past 50 years did the global demand for oil contract. In all other years it grew, quite often by more than $3 \%$ on an annual basis. Over the whole period (1966-2015), the compound annual average growth rate of oil demand was $1.94 \%$. Throughout all of the IEA's scenarios (2013-2040), this rate will slow down to 0.88\% (Current Policies Scenario), $0.43 \%$ (New Policies Scenario), or even $-0.85 \%$ (450 Scenario) [35].

\section{Can OPEC cope with these challenges?}

In light of these challenges, observers have declared OPEC dead as a cartel. There are four major reasons why this view is misguided. 


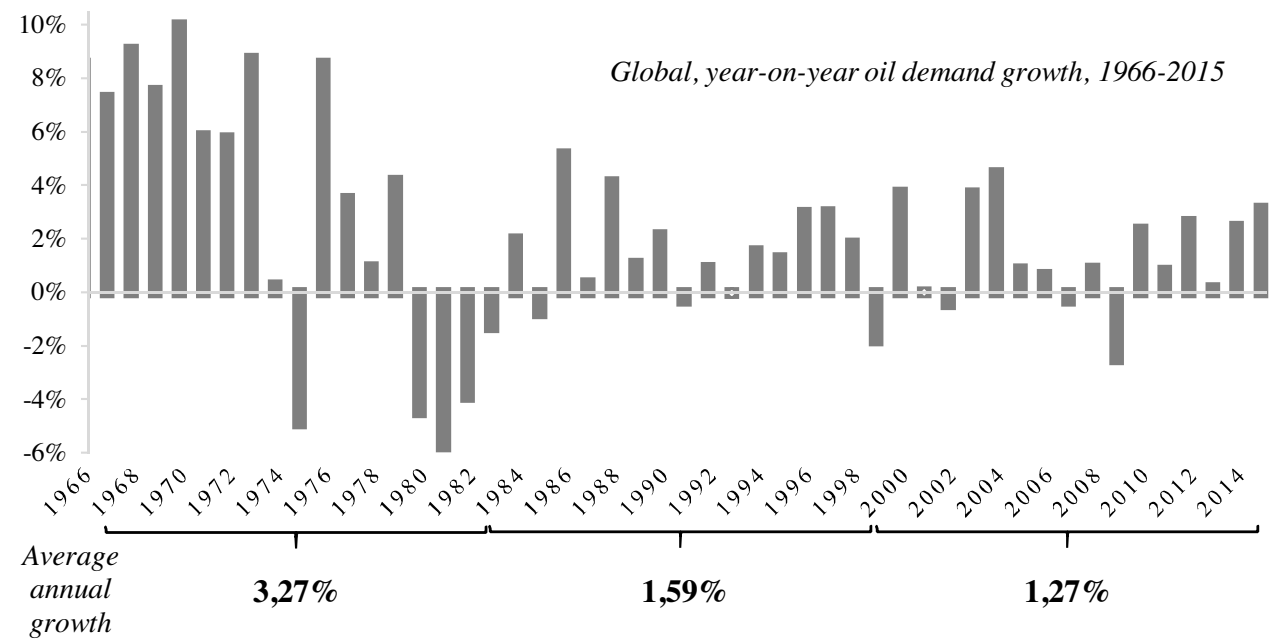

Source: BP Statistical Review of World Energy, June 2016.

Fig. 2. Growth in global oil demand is slowing.

First, OPEC never really was a cartel, let alone an omnipotent one. It only began to enact production targets since 1982 and, even then, it was not very successful. Despite OPEC's efforts to function as a cartel, the oil price plummeted in the first half of the 1980s. Most, if not all OPEC countries cheated on their allocated production targets until Saudi Arabia's patience was exhausted and the Kingdom decided to flood the market in 1986, in order to regain market share and punish the cheaters [6]. Colgan finds that the cartel has overproduced a staggering $96 \%$ of the time in the period 1982-2009 [36].

Second, OPEC's reserves are not stranded yet. OPEC still commands the largest conventional oil reserves. Especially the Gulf members of OPEC have very low production costs. If oil is stranded due to climate policies, it will most likely be the most expensive, risky and polluting fields, such as the Arctic, the ultra-deepwater fields, and the tar sands. Cherp et al. find that a peak in oil demand due to climate policies could even lead to a higher concentration of production in the hands of those states holding the largest conventional oil reserves, which are generally cheaper and less carbon-intensive [37].

Third, OPEC has demonstrated a remarkable flexibility and resilience during its lifetime. As mentioned, it was not created as a price cartel. Supply management only became a focus for the organization in the 1980s. The organization has survived various price crashes, as well as the emergence of the North Sea in the 1970s, Alaska in the 1980s, offshore oil production in the 1990s and biofuels in the 2000s-all of which were seen as existential threats [38]. Crucially, OPEC even hang together when the Saudis inflicted a lot of pain on their fellow cartel members in the late 1980s. Most curiously, OPEC oil ministers have continued to meet in Vienna even when they were at war with each other, such as Iraq and Iran in the 1980s (see Picture 1), Iraq and Kuwait in the 1990s, and Iran and Saudi Arabia today (who are fighting proxy wars in Yemen and Syria). As Antoine Halff, a former IEA oil market specialist, has convincingly argued: 'OPEC has changed and the idea that giving up on supply management means repudiating what the group is all about only focuses on a limited period of its history and confuses one stage of policy with the essence of the group [39,51].' In this flexibility also lies the key to understand why OPEC is the only commodity organization to have survived, whereas earlier commodity agreements (including for tin, coffee, and natural rubber) have faltered and disappeared.

Finally, OPEC will not wither away quickly because it still proves useful for its member countries, as is most vividly illustrated by the

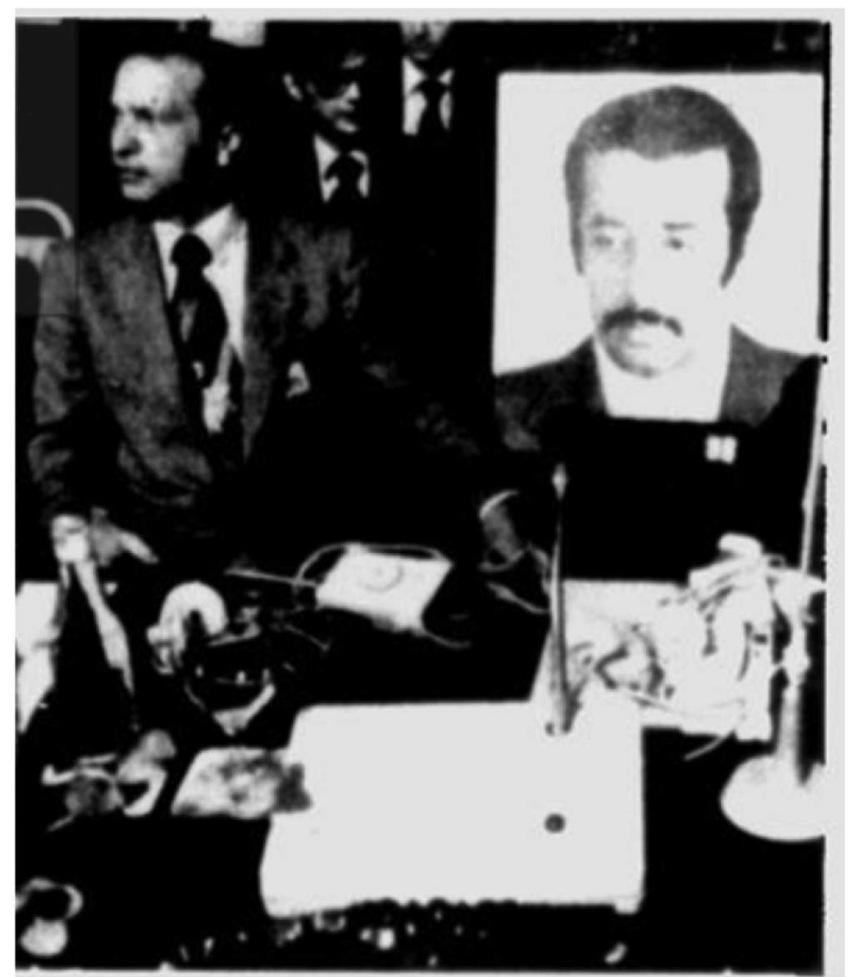

Picture 1. Illustration of OPEC's resilience: The Iranian deputy minister of petroleum, left, sits next to a portrait of the nation's oil minister who was captured by Iraqi troops. The photo was placed on an empty chair during the OPEC meeting of 1980 .

Source: The Prescott Courier, Dec. 15, 1980.

recent re-entries of Indonesia and Gabon to the club. The re-entry of Indonesia is most remarkable since the country has become a net importer. Yet, for its members, OPEC is useful as a forum to share information, as a forum for deliberation, and most notably, a source of prestige. There is a persistent rational myth that OPEC is a powerful cartel [36]. International media are obsessed with OPEC meetings, outcomes and declarations, even if the group's (long-term) impact on oil prices is heavily disputed. Intermittent attempts in the US to put in place a bill against OPEC market manipulation are testimony to the rational myth that OPEC is almighty. 


\section{How could OPEC adapt?}

OPEC's endurance amidst the tectonic changes that have taken place in the global petroleum market has been called an 'enigma of world politics', and the organization itself has been referred to as a 'striking anachronism [22]'. Students of international relations know however that international organizations rarely die [40]. Robert Keohane famously stated that international institutions are 'easier to maintain than to construct [41].' There are many examples of international organizations that have outlived their original mandate. Think of NATO's resilience after the end of the Cold War [42], the World Bank's endurance after the postwar reconstruction of Europe, or the Bank for International Settlements surviving the Great Depression and the Second World War [43]. In the same vein, it is conceivable that OPEC survives the transition to a post-carbon society, as long as it finds a niche for itself that proves valuable to its member states.

Other international energy organizations such as the IEA have been busy for years to adapt to major shifts in the global energy landscape [44]. The IEA has been quite successful in this regard, and is touted as a model for the reform of other global institutions [45]. Yet, other international energy bodies have been much slower to adapt and some even stick around without being very meaningful. A case in point is the Energy Charter Treaty, which has been in complete disarray since Russia's formal withdrawal in 2009, despite recent attempts to reinvigorate the organization [46]. The key question thus becomes whether OPEC countries will engage in a far-reaching examination of the organization's mission and toolbox, or whether the club will sink into oblivion. A systematic account of the history of global energy governance has shown that oil exporters might engage in institutional innovation when they are dissatisfied with the level of their oil revenues [47]. The current low oil prices might thus provide a window of opportunity to reform OPEC.

Over the short to medium term, OPEC might continue to serve as a forum to facilitate attempts at managing oil supply. For all the doubts expressed about it, the recent Algiers signals that there still exists a willingness to intervene and stabilize oil markets in spite of the rhetoric that the oil market should now manage itself.

Toward the longer term, as the world shifts away to cleaner fuels, OPEC could provide a valuable framework for exchanging critical information among member states about the implications of this shift. This could be technical cooperation on technologies such as CCS, which may play their role in the transition and prove to be another source of income for OPEC countries out of their depleted oil and gas wells. But it could also entail the sharing of best practices of how to make a national economy less dependent on the revenues from the foreign sales of crude. Despite many attempts to diversify petro-economies, there are only scant examples of success (e.g., Indonesia, Malaysia and Dubai), and it can be questioned whether these models can be replicated [31]. OPEC's Secretariat could become an information clearing-house to share information on what works and what does not in particular circumstances.

\section{Implications for research}

The link between fossil fuels and climate change is a much overlooked subject of study. Energy and climate change have long been two distinct policy silos, each with its own set of epistemic communities, bureaucrats, experts, and advocacy networks. Oil traders have long tended to focus on OPEC meetings and ignore the UN climate process, while climate wonks have typically turned a blind eye to OPEC meetings. This was most vividly illustrated in December 2015, when few observers and media reports noted the linkages between the simultaneous meetings in Vienna (OPEC) and in Paris
(COP21). This perspective argues that the mutual neglect between climate and energy is no longer tenable, and it identifies three promising avenues for further research.

First, the geopolitics of oil and climate change are intimately interconnected, but the interconnections are not well understood. The conventional view of the geopolitics of energy is that it is all about 'scarcity' and 'access to fields'. This dominant view is often reproduced in media reports about recent developments in the South China Sea, the Mediterranean or the Artic, which are framed as 'energy battles'. In a carbon-constrained world, the geopolitics of energy will revolve around 'abundance' and 'access to markets' [52]. The geopolitical implications of 'stranded assets' and of the shift to renewables merit more attention than they have so far received [48].

A second key research question concerns the adaptation of OPEC as an organization to the shifts in its external environment. OPEC's recent, bumpy history raises many interesting research questions. Why have former members Indonesia and Gabon decided to re-enter the organization? Why did OPEC and Russia reach an agreement in September 2016 to freeze production in spite of the failed talks in April? Will the oil producers follow through on their agreement and, if so, can they turn the tides of low oil prices? Can OPEC play a constructive role in global energy and climate governance, for example in a supply-side climate policy scheme [49], or will it mainly act as a regime spoiler [50]?

A third avenue focuses on how the petrostates within OPEC could diversify their economies. 'Sowing the oil' to diversify the economy has been a longstanding goal for many oil exporters who want to escape the ailments of the resource curse, or face a declining resource base. Yet, there are only a few successful examples of such diversification and questions can be raised over whether these examples constitute 'models' that can be replicated by others. A particularly important question in this regard is whether Saudi Arabia's plan to diversify the national economy is likely to be sustained and the conditions under which it can be successful.

\section{Acknowledgements}

I am grateful to Jeff Colgan, Andreas Goldthau and Benjamin Sovacool for their helpful comments on an earlier version of this perspective.

\section{References}

[1] UNEP and BNEF, Global Trends in Renewable Energy Investment 2016. http:// fs-unep-centre.org/sites/default/files/publications/ globaltrendsinrenewableenergyinvestment2016lowres_0.pdf.

[2] (a) C. McGlade, P. Ekins, The geographical distribution of fossil fuels unused when limiting global warming to 2 [deg] C, Nature 517 (7533) (2015) 187-190;

(b) C. McGlade, P. Ekins, Un-burnable oil: an examination of oil resource utilisation in a decarbonised energy system, Energy Policy 64 (2014) 102-112.

[3] IMF, World Economic Outlook Database, 2016, April, Available at: https:// www.imf.org/external/pubs/ft/weo/2016/01/weodata/index.aspx.

[4] OPEC Annual Statistical Bulletin 2015. Available at: http://www.opec.org opec_web/static_files_project/media/downloads/publications/ASB2015.pdf.

[5] OPEC, OPEC 168th Meeting Concludes, 2015, Press Release No 8/2015, Vienna, Austria, 4 December. Available at: http://www.opec.org/opec_web/en/press_ room/3193.htm.

[6] Bassam Fattouh, Anupama Sen, The past, present and future role of OPEC, in: T. Van de Graaf, B.K. Sovacool, A. Ghosh, F. Kern, M.T. Klare (Eds.), The Palgrave Handbook of the International Political Economy of Energy, Palgrave Macmillan, 2016, pp. 73-94.

[7] IEA, Medium-Term Oil Market Report, 201612 (February).

[8] OPEC, 170th (Extraordinary) Meeting of the OPEC Conference, 2016 (Press Release No 11/2016, Algiers, Algeria, 28 September, Available at: http://www. opec.org/opec_web/en/press_room/3706.htm).

[9] Thijs Van de Graaf, Toxic mix of oil and politics threatens Libya's cohesion, in: World Politics Review, 2014 (March 13).

[10] IEA, Oil Market Report, 2016, August 11, Available at: https://www.iea.org/ media/omrreports/fullissues/2016-08-11.pdf.

[11] Ed Crooks, The death of OPEC? in: FT Energy Source, 2016 (May 30). 
[12] Dmitry Zhdannikov, Rania El Gamal, Exclusive: shift in saudi oil thinking deepens OPEC split, in: Reuters, 2016 (May 5).

[13] (a) William M. Brown, Herman Kahn, Why OPEC is vulnerable, in: Fortune, 1980, pp. 66-69 (July 14);

(b) J. Amuzegar, OPEC's seventh life Middle East Policy 5 (3) (1997) 25.

[14] Tom Randall, Citi: oil could plunge to $\$ 20$, and this might be 'the end of OPEC', in: Bloomberg, 2015 (Feb. 9).

[15] E. Morse, Welcome to the new oil order, in: Financial Times, 2016 (Jan. 28).

[16] F. van der Ploeg, Fossil fuel producers under threat, Oxf. Rev. Econ. Policy 32 (2) (2016) 206-222.

[17] (a) M. Klare, Rising Powers, Shrinking Planet: The New Geopolitics of Energy, Macmillan, 2009;

(b) M. Klare, The Race for What's Left: The Global Scramble for the World's Last Resources, Macmillan, 2012.

[18] Global Agenda Council on the Future of Oil \& Gas, Future Oil Demand Scenarios, World Economic Forum, 2016 (April 2016) http://www3.weforum. org/docs/Future_Oil_Demand_Scenarios.pdf.

[19] G. Bridge, A. Wood, Less is more: spectres of scarcity and the politics of resource access in the upstream sector, Geoforum 41 (2010) 565-576.

[20] John Kemp, Doha meeting might not matter much for oil prices, in: Reuters, 2016 (April 15).

[21] IEA, Medium-Term Gas Market Report, IEA/OECD, Paris, 2014.

[22] A.M. Jaffe, E.L. Morse, OPEC: can the cartel survive another 50 years? in: J.H. Kalicki, D.L. Goldwyn (Eds.), Energy and Security: Strategies for a World in Transition, Woodrow Wilson Center Press, Washington, D.C, 2013.

[23] Congressional Testimony of Antoine Halff before the Committee on Energy and Natural Resources, US Senate, 2nd Session, 114th Congress, January 19, 2016

[24] IEA, World Energy Outlook 2015, OECD/IEA, Paris, 2015.

[25] EIA, Short-Term Energy Outlook, 2016, September 7, Available at: https:// www.eia.gov/forecasts/steo/report/us_oil.cfm.

[26] Congressional Testimony of Antoine Halff before the Committee on Energy and Natural Resources, US Senate, 2nd Session, 114th Congress, January 19 2016. Available at: http://energypolicy.columbia.edu/sites/default/files/ energy/Halff\%20Senate\%20ENR\%20Testimony_2016.01.19.pdf.

[27] J. Rogelj, A. Reisinger, D.L. McCollum, R. Knutti, K. Riahi, M. Meinshausen, Mitigation choices impact carbon budget size compatible with low temperature goals Environ. Res. Lett. 10 (7) (2015) 075003.

[28] UNEP, The Emissions Gap Report 2014: A UNEP Synthesis Report, UNEP, Nairobi, 2014

[29] J. Rogelj, M. Schaeffer, M. Meinshausen, R. Knutti, J. Alcamo, K. Riahi, W. Hare Zero emission targets as long-term global goals for climate protection, Environ. Res. Lett. 10 (10) (2015) 105007.

[30] Amy Myers Jaffe, The role of the US in the geopolitics of climate policy and stranded oil reserves, Nat. Energy 6 (October) (2016), 2016.

[31] T. Van de Graaf, A. Verbruggen, The oil endgame: strategies of oil exporters in a carbon-constrained world, Environ. Sci. Policy 54 (2015) 456-462.

[32] C. McGlade, P. Ekins, The geographical distribution of fossil fuels unused when limiting global warming to 2 [deg] C, Nature 517 (7533) (2015) 187-190.

[33] (a) UNEP, Emissions Gap Report, 2015;

(b) Kelly Levin, Taryn Fransen, Insider: why are INDC studies reaching different temperature estimates, in: WRI Blog Post, 2015, November 9, Available at http://www.wri.org/blog/2015/11/insider-why-are-indc-studiesreaching-different-temperature-estimates.
[34] Carbon Tracker Initiative, Oil Demand: Comparing Projections and Examining Risks, 2014, Available from http://www.carbontracker.org/wp-content/ uploads/2014/05/Chapter1ETAdemandfinal1.pdf.

[35] International Energy Agency, World Energy Outlook 2015, IEA/OECD, Paris, 2015.

[36] J.D. Colgan, The emperor has no clothes: the limits of OPEC in the global oil market, Int. Organ. 68 (03) (2014) 599-632.

[37] A. Cherp, J. Jewell, V. Vinichenko, N. Bauer, E. De Cian, Global energy security under different climate policies, GDP growth rates and fossil resource availabilities, Clim. Change 136 (1) (2016) 83-94.

[38] Javier Blas, OPEC: hold those obituaries, in: Financial Times, 2012 (June 18).

[39] Antoine Halff, OPEC is not dead-it is adapting, in: Financial Times, 2016 (June 2).

[40] S. Strange, Why do international organizations never die? in: Autonomous Policy Making by International Organizations, 1998, pp. 213-220.

[41] Robert O. Keohane, After Hegemony: Cooperation and Discord in the World Political, 1984.

[42] C.A. Wallander, Institutional assets and adaptability: NATO after the Cold War Int. Organ. 54 (04) (2000) 705-735.

[43] P. Bernholz, Are international organizations like the Bank for International Settlements unable to die? Rev. Int. Organ. 4 (4) (2009) 361-381.

[44] (a) T. Van de Graaf, D. Lesage, The International Energy Agency after 35 years: reform needs and institutional adaptability, Rev. Int. Organ. 4 (3) (2009) 293-317;

(b) T. Van de Graaf, Obsolete or resurgent? The International Energy Agency in a changing global landscape, Energy Policy 48 (2012) 233-241; (c) T. Van de Graaf, The IEA, the new energy order and the future of global energy governance, in: Dries Lesage, Thijs Van de Graaf (Eds.), Rising Powers and Multilateral Institutions, Palgrave Macmillan, UK, 2015, pp. 79-95.

[45] S. Patrick, N. Egel, The International Energy Agency's hybrid model: how it manages rising powers-for the benefit of everyone, in: Foreign Affairs, 2016, August 9, Available at: https://www.foreignaffairs.com/articles/2016-08-09/ international-energy-agencys-hybrid-model.

[46] P. Aalto, The new International Energy Charter: instrumental or incremental progress in governance? Energy Res. Soc. Sci. 11 (2016) 92-96.

[47] J.D. Colgan, R.O. Keohane, T. Van de Graaf, Punctuated equilibrium in the energy regime complex, Rev. Int. Organ. 7 (2) (2012) 117-143.

[48] (a) D. Scholten, R. Bosman, The geopolitics of renewables; exploring the political implications of renewable energy systems, Technol. Forecast. Soc. Change 103 (2016) 273-283;

(b) D. Criekemans, The geopolitics of renewable energy: different or similar to the geopolitics of conventional energy? in: ISA Annual Convention, March, 2011, pp. 16-19.

[49] M. Lazarus, P. Erickson, K. Tempest, Supply-side climate policy: the road less taken, in: Working Paper, Stockholm Environment Institute, 2015, pp. 1-24 no. SEI-WP-2015-13 (October)

[50] (a) A. Goldthau, J.M. Witte, Assessing OPEC's performance in global energy Glob. Policy (2011) 31-39;

(b) J. Depledge, Striving for no: Saudi Arabia in the climate change regime, Glob. Environ. Polit. 8 (4) (2008) 9-35.

[51] A.F. Alhajji, D. Huettner, OPEC and other commodity cartels: a comparison, Energy Policy 28 (15) (2000) 1151-1164.

[52] A. Verbruggen, T. Van de Graaf, Peak oil supply or oil not for sale? Futures 53 (2013) 74-85. 